\title{
Impact of tozinameran (BNT162b2) mRNA vaccine on kidney transplant and chronic dialysis patients: 3-5 months followup
}

Iddo Z. Ben-Dov ${ }^{1}$, Yonatan Oster ${ }^{2}$, Keren Tzukert ${ }^{1}$, Talia Alster ${ }^{1}$, Raneem Bader ${ }^{3}$, Ruth Israeli ${ }^{1}$, Haya Asayag ${ }^{1}$, Michal Aharon ${ }^{1}$, Ido Burstein ${ }^{1}$, Hadas Pri-Chen ${ }^{1}$, Ashraf Imam ${ }^{3}$, Roy Abel ${ }^{1}$, Irit Mor-Yosef Levi ${ }^{1}$, Abed Khalaileh ${ }^{3}$, Esther Oiknine-Djian ${ }^{2}, \mathrm{PhD}$, Aharon Bloch ${ }^{1}$, Dana G. Wolf ${ }^{2}$, Michal Dranitzki Elhalel ${ }^{1}$

Departments of Nephrology (1), Clinical Microbiology and Infectious Diseases (2) and Surgery (3), Hadassah Medical Center, Faculty of Medicine, Hebrew University of Jerusalem, Israel

Running title: Tozinameran impact in kidney dialysis and transplant

Abstarct: 249 words, text: 2757 words

Correspondence:

Dr. Iddo Ben-Dov

Department of nephrology, Hadassah Medical Center

Kiryat Hadassah 1, Jerusalem, Israel 921120

email iddo@hadassah.org.il, fax +97226446335 
medRxiv preprint doi: https://doi.org/10.1101/2021.06.12.21258813; this version posted July 17, 2021. The copyright holder for this preprint (which was not certified by peer review) is the author/funder, who has granted medRxiv a license to display the preprint in perpetuity.

All rights reserved. No reuse allowed without permission.

\section{Significance}

Reports on the humoral immunogenicity of SARS-CoV-2 mRNA vaccines in patients with end stage renal disease are scarce, and association with subsequent COVID-19 morbidity is unknown. In this cohort study that included 175 patients treated with dialysis, 252 kidney transplant recipients and 71 control volunteers, the proportion achieving an antibody response was time- and group-dependent, reaching $80 \%, 44 \%$ and $100 \%$ at 3 months post prime inoculation. Personal history of vaccination, positive antibody responses and antibody titers associated with significantly lower risk of COVID-19 infection. Thus, in patients with end stage renal disease, SARS-CoV-2 antibody testing may be warranted after vaccination, to identify nonresponders at higher risk for disease. 
medRxiv preprint doi: https://doi.org/10.1101/2021.06.12.21258813; this version posted July 17, 2021. The copyright holder for this preprint (which was not certified by peer review) is the author/funder, who has granted medRxiv a license to display the preprint in perpetuity.

All rights reserved. No reuse allowed without permission.

\begin{abstract}
Background: Determining the humoral immunogenicity of tozinameran (BNT162b2) vaccine in patients requiring chronic renal replacement therapy, and its impact on COVID-19 morbidity several months after vaccination, will guide risk assessment and subsequent changes in vaccination policy.
\end{abstract}

Methods: In a prospective post-vaccination cohort study with up to 5 months follow-up we studied outpatient dialysis and kidney transplant patients and respective healthcare teams. Outcomes were anti S1/S2 antibody response to vaccine or infection and infection rate during followup.

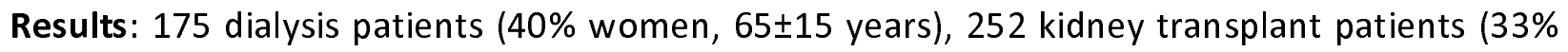
women, $54 \pm 14$ years) and 71 controls ( $65 \%$ women, $44 \pm 14$ years) were followed. Three months or longer after vaccination we detected anti S1/S2 IgG antibodies in $80 \%$ of dialysis patients, $44 \%$ of transplant recipients and $100 \%$ of controls, whereas respective rates after infection were $94 \%, 75 \%$ and $100 \%$. Predictors of non-response were older age, diabetes, history of cancer, lower lymphocyte count and lower vitamin-D levels. Factors associated with lower titers in dialysis patients were modality (hemodialysis vs peritoneal) and high serum ferritin levels. In transplant patients, hypertension and higher calcineurin or mTOR inhibitor drug levels were linked with diminished antibody response. Vaccination associated with fewer subsequent infections $(\mathrm{HR}=0.23, \mathrm{p}<0.05)$. Moreover, higher antibody titers associated with fewer events, HR 0.41 for each unit increased in $\log _{10}$ titer $(p<0.05)$.

Conclusions: Dialysis patients, and more so kidney transplant recipients, mounted reduced antibody response to COVID-19 mRNA vaccination, and lesser humoral response associated 
medRxiv preprint doi: https://doi.org/10.1101/2021.06.12.21258813; this version posted July 17, 2021. The copyright holder for this preprint (which was not certified by peer review) is the author/funder, who has granted medRxiv a license to display the preprint in perpetuity.

All rights reserved. No reuse allowed without permission.

with more infections. Measures to identify and protect non-responsive patients are urgently required. 
medRxiv preprint doi: https://doi.org/10.1101/2021.06.12.21258813; this version posted July 17, 2021. The copyright holder for this preprint (which was not certified by peer review) is the author/funder, who has granted medRxiv a license to display the preprint in perpetuity.

All rights reserved. No reuse allowed without permission.

\section{Introduction}

Vaccinations, both passive and active, changed the natural course of many infectious diseases, affecting both spread and severity. From smallpox through rabies, tetanus and measles, to hepatitis B, as well as many other viral and bacterial infections, vaccines have either eradicated diseases or eliminated the risk for pandemic or endemic catastrophes. Therefore, efforts to develop effective vaccination against COVID-19 started as soon as the impact of this coronavirus on global public health was appreciated. Impressively, effective vaccines were developed and approved at a record time, within less than a year. These active vaccines offer hope for controlling disease spread and reducing illness severity and death rates. Various vaccines are already in use, and data emerging form real-world practice (as from Israel ${ }^{1}$ and other countries) suggests effectivity in prevention of severe disease ${ }^{2}$.

The COVID-19 pandemic brought new challenges to the general population and even more so to patients with end-stage renal disease (ESRD), many of whom have comorbidities now acknowledged as risk factors for severe COVID-19. Aside from logistic challenges summarized elsewhere ${ }^{3}$, these patients, both dialysis-treated and kidney transplant patients, face morbidly and mortality risks that are significantly higher than the general population ${ }^{4,5}$. Unfortunately, it is known from existing vaccine preparations such as anti-hepatitis B virus and the influenza ${ }^{6-9}$, that both dialysis and kidney transplant patients require higher doses and repeat inoculations (i.e. periodic boosts) in order to achieve durable protection ${ }^{10,11}$. This diminished response to vaccination is thought to be secondary to dysfunction of both B and T lymphocytes in ESRD patients, as well as to the immunosuppressant medications taken by transplant recipients (occasionaly also after resuming dialysis). Dendritic cell dysfunction, 
medRxiv preprint doi: https://doi.org/10.1101/2021.06.12.21258813; this version posted July 17, 2021. The copyright holder for this preprint (which was not certified by peer review) is the author/funder, who has granted medRxiv a license to display the preprint in perpetuity.

All rights reserved. No reuse allowed without permission.

described in patients with ESRD ${ }^{12}$ likely compromises vaccination success. As the information available about COVID-19 vaccine effectiveness in dialysis and transplanted patients is limited and short-termed ${ }^{13,14}$, we sought to prospectively follow antibody development in these patients, to compare them with healthy controls and to identify risk factors for diminished humoral response and disease.

\section{Methods}

Setting: Vaccination with tozinameran, Pfizer and BioNTech's BNT162b2 vaccine, commenced in Israel on December 2020-12-20, and immunocompromised patients were of the first priority groups. Prior to initiation of vaccination we launched the COVID-19 mRNA Vaccine Immunogenicity in patients with end stage Renal Disease (COVIReD) prospective cohort study designed to investigate the long-term kinetics and implications of antibody response to COVID19 vaccine and infection in this vulnerable population. We are characterizing the humoral response to COVID-19 infection and vaccination as well as disease occurrence among patients treated with maintenance dialysis, kidney transplant recipients and control subjects at Hadassah Medical Center, a two-campus tertiary medical center in Jerusalem, Israel. Jerusalem was the area with the highest COVID-19 prevalence in Israel ${ }^{15,16}$ (and during the pandemic more than 4,500 COVID-19 patients were admitted to our institution). We recruited control subjects from amongst medical, nursing and administrative healthcare staff at the dialysis unit and/or the transplantation clinic. 
medRxiv preprint doi: https://doi.org/10.1101/2021.06.12.21258813; this version posted July 17, 2021. The copyright holder for this preprint (which was not certified by peer review) is the author/funder, who has granted medRxiv a license to display the preprint in perpetuity.

All rights reserved. No reuse allowed without permission.

Clinical methods: The study has been approved the the Haddasah Medical Organization's Helsinki Committee and has been conducted in accordance with the declaration of Helsinki. Written informed concent was obtained from participants. Blood samples were taken from dialysis and transplant patients during routine visits, after obtaining informed consent, at several designated time-windows during the vaccination period: at baseline (namely, before administration of the first vaccine dose), 10-20 days after the first vaccine, 2-6 weeks after the second vaccine inoculation (typically scheduled 21 days after the first inoculation) and 3 months or longer after the first vaccination. Most hemodialysis patients and controls provided samples at all or most time-points while transplant and peritoneal dialysis patients provided samples sporadically during their scheduled outpatient visits.

Laboratory methods: All serum samples were tested at Hadassah's clinical virology laboratory, using kits supplied by the Israeli Ministry of Health. Anti-SARS-2 IgG antibodies were quantified using LIAISON SARS-CoV-2 S1/S2 IgG (DiaSorin) and ARCHITECT SARS-CoV-2 IgG II (Abbott) immunoassays, and the former kit results are reported here. In addition, before as well as after vaccination we tested nasal swabs for viral RNA using qPCR assays when clinically or epidemiologically indicated, but did not perform routine PCR screening except in staff. Inpatient and outpatient diagnoses, patient demographics and serology, virology and additional selected laboratory results (see Table 1) were extracted for the period between 2020-03-01 and up to patient vaccination, by the institution's information systems. 
medRxiv preprint doi: https://doi.org/10.1101/2021.06.12.21258813; this version posted July 17, 2021. The copyright holder for this preprint (which was not certified by peer review) is the author/funder, who has granted medRxiv a license to display the preprint in perpetuity.

All rights reserved. No reuse allowed without permission.

Statistical analysis: Deidentified clinical information and laboratory data and metadata were stored as spreadsheets, and processed using $\mathrm{R}$ base and related statistical packages. Clinical characteristics of study participants were summarized by group using means \pm SD or medians and ranges, as appropriate. Right-skewed variables (e.g. antibody titers) were $\log _{10}$-transformed prior to statistical testing. Between-group differences in baseline clinical characteristics were assessed using ANOVA or chi squared. Statistical symbols embedded with in plots reflect MannWhitney $U$ test results. Potential clinical predictors of antibody response and disease (COVID-19 infection) were examined using mixed-effects linear (for antibody titers) and generalized linear (for dichotomous antibody results) and Cox proportional hazards models, respectively, using 'Ime4'17, 'coxme' (mixed effects cox models) and 'survival' ${ }^{18}$ packages. Repeated measures were accounted for by including patient ID as a random effect in these models. Model outputs are presented using the 'sjPlot' package ${ }^{19}$. Predictions based on these models were generated and plotted using the 'ggeffects' package ${ }^{20}$. For Cox modeling of COVID-19 infection events with vaccination or serological test results as independent variables, the respective time-dependent covariates were constructed as suggested by Therneau et al using the 'tmerge' function of the 'survival' R/Bioconductor package ${ }^{18}$. We generated plots in R using the 'ggplot2'21 and 'NMF'22 packages.

\section{Results}

One hundred and seventy-five patients treated with dialysis (152 hemodialysis and 23 peritoneal dialysis), 252 kidney transplant patients and 71 nephrology healthcase team control participants provided specimens for serological analyses. Table $\mathbf{1}$ summarizes their 
medRxiv preprint doi: https://doi.org/10.1101/2021.06.12.21258813; this version posted July 17, 2021. The copyright holder for this preprint (which was not certified by peer review) is the author/funder, who has granted medRxiv a license to display the preprint in perpetuity. All rights reserved. No reuse allowed without permission.

demographic and clinical characteristics. Specimens were provided before, between and/or after administration of vaccine doses and COVID-19 infections, as desctibed in Table S1 (online supplement). Infections occurred prior to vaccine availability in $7.0 \%, 9.1 \%$ and $9.1 \%$ of control, dialysis-treated and transplant participants, respectively. Twenty percent, $31 \%$ and $17 \%$ of these respective prevalent cases were identified solely via positive serology.

Of our study participants, $82-83 \%$ received at least 1 dose of tozinameran and $77-79 \%$ received 2 inoculations, while among participants who were not infected with COVID-19 prior to vaccine availability, complete vaccination rates were $83-85 \%$. Figure S1 (in the online supplement) shows the timeline of COVID-19 infections in our cohort, and of vaccination events, beginning at the epidemic onset.

Serological results: Figure 1a and Table S1 show the binary serological outcome among the 3 groups of participants at several occasions in relation to vaccination and disease. While $100 \%$ of control subjects generated borderline or above antibody levels when sampled 22-71 days after the first vaccination, only $80 \%$ of dialysis patients - and $44 \%$ of transplant recipients - achieved such levels when tested 3 months or more after the first dose (range 90-139 days). In unvaccinated COVID-19 survivors, the respective positive (incl. borderline) antibody rates were $100 \%, 94 \%$ and $75 \%$. Predictors of lack of anti-spike IgG response after single or double vaccine inoculation were being a dialysis (odds ratio $=39,95 \% \mathrm{Cl} 6.0-2.6 \times 10^{2}, \mathrm{p}<0.001$ ) or transplant patient $\left(\mathrm{OR}=7.1 \times 10^{2}, 95 \% \mathrm{Cl} 7.1-7.0 \times 10^{3}, \mathrm{p}<0.00001\right)$ compared to control, shorter time interval between vaccination and testing (OR=0.97 per day, 95\% $\mathrm{Cl} 0.96-0.98, p<0.00001$, Figure 1b), age above the median (58 years) $(\mathrm{OR}=3.7,95 \% \mathrm{Cl} 1.6-8.8, \mathrm{p}<0.01$, and see Figure $1 \mathrm{c}$ ), personal 
medRxiv preprint doi: https://doi.org/10.1101/2021.06.12.21258813; this version posted July 17, 2021. The copyright holder for this preprint (which was not certified by peer review) is the author/funder, who has granted medRxiv a license to display the preprint in perpetuity. All rights reserved. No reuse allowed without permission.

history of cancer $(\mathrm{OR}=5.9,95 \% \mathrm{Cl} 1.3-27, \mathrm{p}<0.05)$ or diabetes $(\mathrm{OR}=2.6,95 \% \mathrm{Cl} 1.1-6.4, \mathrm{p}<0.05)$, as well as lower lymphocyte count $(\mathrm{OR}=0.49,95 \% \mathrm{Cl} 0.29-0.82$, per 1,000 cells $/ \mu \mathrm{l}, \mathrm{p}<0.01)$ and (in subjects with available data) lower vitamin D levels (OR=0.94, 95\% Cl 0.89-1.00, per $1 \mathrm{ng} / \mathrm{ml}$, $p<0.05)$

Quantitative serological results: Figure $\mathbf{2 a}$ and Table S2 show the numerical serological outcome among the 3 groups at several occasions, in relation to vaccination and disease. The quantitative titers parallel the qualitative results presented above. Linear mixed effects models indicated that in addition to the timepoint of testing, IgG titers depended on the study group, being $0.54 \log _{10}$ lower values in dialysis patients and $1.29 \log _{10}$ lower in transplant patients, compared to controls (both $\mathrm{p}<0.00001$ ). $\log _{10}$ titers were 0.01 lower per year of age $(p<0.00001)$. In addition, higher lymphocyte counts $\left(0.12 \log _{10}\right.$ per 1,000 cells $\left./ \mu l, p<0.01\right)$ and lower ferritin levels $\left(0.03 \log _{10}\right.$ per $\left.100 \mathrm{ng} / \mathrm{ml}, \mathrm{p}<0.05\right)$ were linked with higher antibody titers. Figure $\mathbf{2} \mathbf{b}$ depicts antibody titers in participants that were vaccinated twice according to the time elapsed from the prime dose. Predictions based on linear mixed effects models (with time post vaccination introduced as an independent variable using splines and the time*group interaction also included in the model) are shown in Figure $\mathbf{2 c}$ and $\mathbf{2 d}$. A plateau is notable to emerge in controls and dialysis patients at $\sim 55$ days post 1 st vaccination, while in transplant recipients a mild incline may persist beyond this period.

Group-specific associations: In transplant recipients, the step-up in antibody titers after the 2nd vaccination was significantly greater in younger $(<55$ years) compared to older patients (Figure 
medRxiv preprint doi: https://doi.org/10.1101/2021.06.12.21258813; this version posted July 17, 2021. The copyright holder for this preprint (which was not certified by peer review) is the author/funder, who has granted medRxiv a license to display the preprint in perpetuity.

All rights reserved. No reuse allowed without permission.

S2). In fact, 3 months or longer after the prime dose, $60 \%$ of younger patients but only $24 \%$ of older transplant patients had a categorically positive titer of antibodies. Time from transplantation was associated with antibody titers in a non-linear manner; compared to patients transplanted 6-18 months before antibody testing (having lowest levels), recipients less than 6 months after transplantation had $0.92 \log _{10}$ higher titers $(p<0.01)$ and recipients of 18 months or longer duration had $0.30 \log _{10}$ higher titers $(p<0.01)$. In models including age, timing of antibody testing and time after transplantation, titers were $0.20 \log _{10}$ lower in patients with diagnosis of hypertension $(p<0.05)$ and $0.51 \log _{10}$ lower with diagnosis of anemia $(p<0.05)$. The aggregated immunosuppressive drug level - tacrolimus, cyclosporin A (transformed by multiplying by 0.06$)$, everolimus and sirolimus - was also linked with lower titers $\left(0.063 \log _{10}\right.$ per $\mathrm{ng} / \mathrm{ml}, \mathrm{p}<0.05$, Figure $\mathbf{S 2 c}$ ), however this association was not significant when accounting for time after transplantation $\left(0.055 \log _{10}\right.$ lower per $\left.\mathrm{ng} / \mathrm{ml}, \mathrm{p}=0.08\right)$. Serum creatinine and estimated glomerular filtration rate (CKD-EPI equation) did not associate with titers.

In dialysis patients, unique predictors of antibody titers were: (1) modality; peritoneal dialysis patients had 0.41 higher $\log _{10}$ titer compared to haemodialysis patients (adjusted for age and time post vaccination, $p<0.01$ ). (2) Ferritin levels were linked with lower $\log _{10}$ titers (0.03 per $100 \mathrm{ng} / \mathrm{ml}, \mathrm{p}<0.05$ ) (Figure S3). Conversely, dialysis vintage, comorbid conditions and averaged urea reduction rate (in hemodialysis patients) were not associated with antibody titers.

Occurrence of COVID-19: Ninety six study participants had COVID-19 infection before or after the vaccination period. Vaccine inoculations, introduced as time varying covariates, are seen in 
medRxiv preprint doi: https://doi.org/10.1101/2021.06.12.21258813; this version posted July 17, 2021. The copyright holder for this preprint (which was not certified by peer review) is the author/funder, who has granted medRxiv a license to display the preprint in perpetuity.

All rights reserved. No reuse allowed without permission.

Figure 3a (and Figure S4a) to inversely associate with COVID-19 infection risk, after vaccine availability. This relationship was marginally stronger in controls compared to both ESRD groups ( $p$-values for the interactions $\sim 0.1$ ), but was significantly weaker in older compared to younger subjects (Figure $\mathbf{3 b}$ and Figure $\mathbf{S 4 b}$ ), possibly owing to lower baseline risk in this subgroup ( $p$ value for the interaction 0.013 ).

Moreover, positive (including borderline) anti-SARS-CoV-2 IgG serology after vaccination was linked with lower risk of COVID-19 infection (Figure 3c and Figure S4c), hazards ratios 0.23 (95\% Cl 0.05-0.99). Likewise, quantitative IgG titers were linked with significantly lower COVID19 risk (Figure 3d and Figure $\mathbf{S 4 d}$ ). See additional analyses including mortality as supplementary

\section{Supplementary Text and Figure S5.}

Post-COVID-19 serology: SARS-CoV-2 S1/S2 IgG antibody titers after COVID-19 infection were lower compared to vaccine-driven antibodies in controls, but not in ESRD patients. In fact, in transplant recipients the opposite was true (Figure 4).

\section{Discussion}

This prospective study was designed to follow serum antibody levels after COVID-19 vaccination and/or disease in patients requiring chronic renal replacement therapy, and to estimate associations of vaccine inoculation and the resulting humoral response with subsequent COVID19 infections. Healthcare team personnel (nursing, medical, assisting and administrative staff, working in the respective dialysis units and/or in the transplantation clinic) served as controls. Anti-spike antibody positivity rates and levels did not differ between groups at baseline. 
medRxiv preprint doi: https://doi.org/10.1101/2021.06.12.21258813; this version posted July 17, 2021. The copyright holder for this preprint (which was not certified by peer review) is the author/funder, who has granted medRxiv a license to display the preprint in perpetuity.

All rights reserved. No reuse allowed without permission.

However, dialysis and more so kidney transplant patients had significantly lower positive response rates and titers both after the prime administration and after the $2 \mathrm{nd}$, compared to the staff. These findings are in line with previous studies in kidney dialysis and transplant patients (reported predominanltly as "letters to the editor"). Not previously reported, we found that vaccination was linked with lower risk of COVID-19 infection in all groups; however, the effect was smaller in the ESRD patients.

Prior to vaccination, positive serology was found in a small percentage $(<10 \%)$ of participants, indicating past infection with SARS-CoV-2 virus. About one third of these infections were not detected or suspected previously, despite strict screening measures in dialysis patients - questioning for possible contacts with verified COVID-19 patients, for any risk factor for exposure (as recent flight, attending crowded event or living in neighborhoods with high rates of infection), and for symptoms that can suggest active infection, as well as actively measuring body temperature and repeated SARS-CoV-2 nucleic acid quantification by nasal swabs after possible exposure.

There are significant age differences between the control group and the dialysis patient group, which is compatible with the average age of dialysis patients. As significant differences of antibody levels were found in the vaccine's clinical study, where older individuals had lower antibody titer (also observed among our study partitipants), we included age in the statistical models, and thus report a significant age-adjusted relationship between study group and antibody titers.

Only $32 \%$ of transplant patients and $73 \%$ of dialysis patients had a positive (including borderline) antibody test after the second vaccination, improving by 3 months to $44 \%$ and $80 \%$ 
medRxiv preprint doi: https://doi.org/10.1101/2021.06.12.21258813; this version posted July 17, 2021. The copyright holder for this preprint (which was not certified by peer review) is the author/funder, who has granted medRxiv a license to display the preprint in perpetuity.

All rights reserved. No reuse allowed without permission.

respectively, yet still having significantly lower antibody titers compared with controls. This raised the question whether additional vaccine boosts or higher doses are needed in this patient population, as was previously reported for hepatitis B vaccine $e^{10}$.

Strikingly, many fully vaccinated transplat patients were identified with no detectable antibodies, and some developed severe COVID-19 after infection. Similar findings, of reduced response to two-dose regimen of tozinameran, were reported previously in dialysis patients ${ }^{24-}$ ${ }^{27}$, kidney transplant recipients ${ }^{28-30}$, as well other receivers of solid-organ alografts ${ }^{31-33}$, although follow-up periods were usually much shorter than in our study and there were typically no investigations of links with infection.

During the study period, infection rates in Israel including Jeusalem dropped drastically. However, we found that COVID-19 infection following vaccination was independently associated with lower post-vaccination antibody titers, suggesting benefit from personal history of vaccination on top of herd immunity. This association was reported previously with neutralizing antibody assays $^{34}$ but not with antibodies detected by common ELISA. This association has clinical and epidemiological importance; if we can identify individuals at high risk of infection, we can apply individualized protective measures, while easing on the general population, or introduce additional vaccination boosts for that specific vulnerable group. The findings that lower lymphocyte counts and higher serum levels of immunosuppressive medications are associated with lesser antibody response also suggest the need for additional vaccination for immunosuppressed patients. Intrigingly, controls mounted lower anti S1/S2 titers after infection compared to vaccination, while the reverse was true in ESRD patients. This can be in part explained in transplant patients by the observation that during and shorly after 
medRxiv preprint doi: https://doi.org/10.1101/2021.06.12.21258813; this version posted July 17, 2021. The copyright holder for this preprint (which was not certified by peer review) is the author/funder, who has granted medRxiv a license to display the preprint in perpetuity.

All rights reserved. No reuse allowed without permission.

infection, immunosuppressant medication doese were typically reduced, except corticosteroids which were often temporarily increased.

There are several limitations to our study. This is a single center study, and may not represent the larger ESRD community when considering future vaccination policy, although we believe that the study is large enough to facilitate further research. A longer follow-up period can enrich the data on antibody titers, although the dramatic rapid decline in COVID-19 prevalence in Israel means that hopefully little new data regarding protectivity will be available. Additionally, COVID-19 infection was defined as positive PCR, regardless of symptoms, but routine screening was not done, and therefore we might have missed several asymptomatic patients. Lastly, we did not report in this study ongoing investigation of cellular immunity or non-IgG antibodies which could add to our understanding of the immune response and protection after vaccination.

In conclusion, we show that ESRD patients exhibit impaired humoral response to two doses of tozinameran, a prototype of mRNA vaccination, manifested either by negative ELISA or lower titers than those of the healthy controls. Of note, a small rise in antibody levels and proportion of responding patiens is evident after three months, suggesting a different time scale of the immune response. Additionally, we show inverse association of lgG titers with the risk of contracting COVID-19 after vaccination. We suggest testing immune-compromised patients for COVID-19 IgG antibodies in order to identify high-risk patients, and to expand research regarding the need for boost doses. 
medRxiv preprint doi: https://doi.org/10.1101/2021.06.12.21258813; this version posted July 17, 2021. The copyright holder for this preprint (which was not certified by peer review) is the author/funder, who has granted medRxiv a license to display the preprint in perpetuity.

All rights reserved. No reuse allowed without permission. 
medRxiv preprint doi: https://doi.org/10.1101/2021.06.12.21258813; this version posted July 17, 2021. The copyright holder for this preprint (which was not certified by peer review) is the author/funder, who has granted medRxiv a license to display the preprint in perpetuity.

All rights reserved. No reuse allowed without permission.

\section{Author Contributions}

- Study conception and design - IZB-D, AK, MDE, DGW

- Data acquisition including patient recruitment - KT, TA, RB, RA, HA, MA, IB, HP-C, Al, RA, $I M-Y L, E O D, A B$

- Data analysis -IZB-D

- Data interpretation -IZB-D, YO, MDE

- Drafting the manuscript-YO, IZB-D, MDE

- Revising the manuscript $-\mathrm{KT}, \mathrm{AK}$

\section{Acknowledgments}

None

\section{Disclosures}

Authors have no disclosures.

\section{Funding}

There was no external funding for this study. 
medRxiv preprint doi: https://doi.org/10.1101/2021.06.12.21258813; this version posted July 17, 2021. The copyright holder for this preprint (which was not certified by peer review) is the author/funder, who has granted medRxiv a license to display the preprint in perpetuity.

\section{References}

1. Haas E, Angulo F, McLaughlin J, et al. Impact and effectiveness of mRNA BNT162b2 vaccine against SARS-CoV-2 infections and COVID-19 cases, hospitalisations, and deaths following a nationwide vaccination campaign in Israel: an observational study using national surveillance data. Lancet (London, England). 05/15/2021 2021;397(10287)doi:10.1016/S0140$6736(21) 00947-8$

2. McDonald I, Murray S, Reynolds C, Altmann D, Boyton R. Comparative systematic review and meta-analysis of reactogenicity, immunogenicity and efficacy of vaccines against SARS-CoV2. NPJ vaccines. 05/13/2021 2021;6(1)doi:10.1038/s41541-021-00336-1

3. Meo S, Bukhari I, Akram J, Meo A, Klonoff D. COVID-19 vaccines: comparison of biological, pharmacological characteristics and adverse effects of Pfizer/BioNTech and Moderna Vaccines. European review for medical and pharmacological sciences. 2021 Feb 2021;25(3)doi:10.26355/eurrev_202102_24877

4. Verna E, Landis C, Brown R, et al. Factors Associated with Readmission in the US Following Hospitalization with COVID-19. Clinical infectious diseases : an official publication of the Infectious Diseases Society of America. 05/20/2021 2021;doi:10.1093/cid/ciab464

5. Lano G, Braconnier A, Bataille S, et al. Risk factors for severity of COVID-19 in chronic dialysis patients from a multicentre French cohort. Clinical kidney journal. 10/21/2020 2020;13(5)doi:10.1093/ckj/sfaa199

6. Johnson DW, Fleming SJ. The use of vaccines in renal failure. Clinical pharmacokinetics. 1992 Jun 1992;22(6)doi:10.2165/00003088-199222060-00003

7. Mastalerz-Migas A, Gwiazda E, Brydak LB. Effectiveness of influenza vaccine in patients on hemodialysis--a review. Medical science monitor : international medical journal of experimental and clinical research. 11/18/2013 2013;19doi:10.12659/MSM.889671

8. Rautenberg P, Teifke I, Schlegelberger T, Ullmann U. Influenza subtype-specific IgA, IgM and IgG responses in patients on hemodialysis after influenza vaccination. Infection. 1988 1988;16(6)doi:10.1007/BF01644539 
medRxiv preprint doi: https://doi.org/10.1101/2021.06.12.21258813; this version posted July 17, 2021. The copyright holder for this preprint (which was not certified by peer review) is the author/funder, who has granted medRxiv a license to display the preprint in perpetuity.

All rights reserved. No reuse allowed without permission.

9. Beyer WE, Versluis DJ, Kramer P, Diderich PP, Weimar W, Masurel N. Trivalent influenza vaccine in patients on haemodialysis: impaired seroresponse with differences for A-H3N2 and A-H1N1 vaccine components. Vaccine. 1987 Mar 1987;5(1)doi:10.1016/0264-410x(87)90008-9

10. Yao T, Shao Z, Wu L, et al. Long-term persistent immunogenicity after successful standard and triple-dosed hepatitis B vaccine in hemodialysis patients: A 3-year follow-up study in China. Vaccine. 04/28/2021 2021;39(18)doi:10.1016/j.vaccine.2021.03.074

11. Miskulin D, Weiner D, Manley H. High-Dose Versus Standard-Dose Influenza Vaccine in Hemodialysis Patients. American journal of kidney diseases : the official journal of the National Kidney Foundation. 2020 Mar 2020;75(3)doi:10.1053/j.ajkd.2019.09.019

12. Kim JU, Kim M, Kim S, et al. Dendritic Cell Dysfunction in Patients with End-stage Renal Disease. Immune network. 2017 Jun 2017;17(3)doi:10.4110/in.2017.17.3.152

13. Heldman M, Limaye A. SARS-CoV-2 Vaccines in Kidney Transplant Recipients: Will They Be Safe and Effective and How Will We Know? Journal of the American Society of Nephrology: JASN. 05/03/2021 2021;32(5)doi:10.1681/ASN.2021010023

14. Kliger A, Silberzweig J. COVID-19 and Dialysis Patients: Unsolved Problems in Early 2021. Journal of the American Society of Nephrology : JASN. 05/03/2021 2021;32(5)doi:10.1681/ASN.2020121766

15. Benenson S, Oster $\mathrm{Y}$, Cohen M, Nir-Paz R. BNT162b2 mRNA Covid-19 Vaccine Effectiveness among Health Care Workers. The New England journal of medicine. 05/06/2021 2021;384(18)doi:10.1056/NEJMc2101951

16. COVID-19 - Government Data. https://data.gov.il/dataset/covid-19

17. Bates D, Mächler M, Bolker B, Walker S. Fitting Linear Mixed-Effects Models Using Ime4. $\begin{array}{llll}\text { Articles. } & J & \text { Stat } & \text { Software }\end{array}$ 2015;67doi:https://www.jstatsoft.org/index.php/iss/article/view/v067i01

18. Therneau TM, Grambsch PM. Modeling Survival Data: Extending the Cox Model. 2000.

19. Lüdecke D. sjPlot: Data Visualization for Statistics in Social Science . 2021. https://CRAN.R-project.org/package=sjPlot

20. Lüdecke D. ggeffects: Tidy Data Frames of Marginal Effects from Regression Models. Journal of Open Source Software. 2021;3(26):772. doi:10.21105/joss.00772 
medRxiv preprint doi: https://doi.org/10.1101/2021.06.12.21258813; this version posted July 17, 2021. The copyright holder for this preprint (which was not certified by peer review) is the author/funder, who has granted medRxiv a license to display the preprint in perpetuity.

All rights reserved. No reuse allowed without permission.

21. Wickham H. ggplot2: Elegant Graphics for Data Analysis. Springer-Verlag New York; 2016.

22. Gaujoux R, Seoighe C. A flexible R package for nonnegative matrix factorization. BMC bioinformatics. 07/02/2010 2010;11doi:10.1186/1471-2105-11-367

23. Walsh E, Frenck R, Falsey A, et al. Safety and Immunogenicity of Two RNA-Based Covid19 Vaccine Candidates. The New England journal of medicine. 12/17/2020 2020;383(25)doi:10.1056/NEJMoa2027906

24. Anand S, Montez-Rath M, Han J, et al. Serial SARS-CoV-2 Receptor-Binding Domain Antibody Responses in Patients Receiving Dialysis. Annals of internal medicine. 05/18/2021 2021;doi:10.7326/M21-0256

25. Simon B, Rubey $\mathrm{H}$, Treipl A, et al. Haemodialysis patients show a highly diminished antibody response after COVID-19 mRNA vaccination compared to healthy controls. Nephrology, dialysis, transplantation : official publication of the European Dialysis and Transplant Association - European Renal Association. 05/17/2021 2021;doi:10.1093/ndt/gfab179

26. Agur T, Ben-Dor N, Goldman S, et al. Antibody response to mRNA SARS-CoV-2 vaccine among dialysis patients - a prospectivecohort study. Nephrology, dialysis, transplantation : official publication of the European Dialysis and Transplant Association - European Renal Association. 04/11/2021 2021;doi:10.1093/ndt/gfab155

27. Grupper A, Sharon N, Finn T, et al. Humoral Response to the Pfizer BNT162b2 Vaccine in Patients Undergoing Maintenance Hemodialysis. Clinical journal of the American Society of Nephrology : CJASN. 04/06/2021 2021;doi:10.2215/CJN.03500321

28. Husain S, Tsapepas D, Paget $\mathrm{K}$, et al. Post-vaccine anti-SARS-CoV-2 spike protein antibody development in kidney transplants recipients. Kidney international reports. 04/23/2021 2021;doi:10.1016/j.ekir.2021.04.017

29. Rozen-Zvi B, Yahav D, Agur T, et al. Antibody response to SARS-CoV-2 mRNA vaccine among kidney transplant recipients: a prospective cohort study. Clinical microbiology and infection : the official publication of the European Society of Clinical Microbiology and Infectious Diseases. 05/03/2021 2021;doi:10.1016/j.cmi.2021.04.028 
medRxiv preprint doi: https://doi.org/10.1101/2021.06.12.21258813; this version posted July 17, 2021. The copyright holder for this preprint (which was not certified by peer review) is the author/funder, who has granted medRxiv a license to display the preprint in perpetuity.

All rights reserved. No reuse allowed without permission.

30. Korth J, Jahn M, Dorsch O, et al. Impaired Humoral Response in Renal Transplant Recipients to SARS-CoV-2 Vaccination with BNT162b2 (Pfizer-BioNTech). Viruses. 04/25/2021 2021;13(5)doi:10.3390/v13050756

31. Boyarsky B, Werbel W, Avery R, et al. Antibody Response to 2-Dose SARS-CoV-2 mRNA Vaccine Series in Solid Organ Transplant Recipients. JAMA. 05/05/2021 2021;doi:10.1001/jama.2021.7489

32. Wadei H, Gonwa T, Leoni J, Shah S, Aslam N, Speicher L. COVID-19 infection in solid organ transplant recipients after SARS-CoV-2 vaccination. American journal of transplantation : official journal of the American Society of Transplantation and the American Society of Transplant Surgeons. 04/23/2021 2021;doi:10.1111/ajt.16618

33. Peled Y, Ram E, Lavee J, et al. BNT162b2 vaccination in heart transplant recipients: Clinical experience and antibody response. The Journal of heart and lung transplantation : the official publication of the International Society for Heart Transplantation. 04/21/2021 2021;doi:10.1016/j.healun.2021.04.003

34. Sui Y, Bekele Y, Berzofsky J. Potential SARS-CoV-2 Immune Correlates of Protection in Infection and Vaccine Immunization. Pathogens (Basel, Switzerland). 01/30/2021 2021;10(2)doi:10.3390/pathogens10020138 
medRxiv preprint doi: https://doi.org/10.1101/2021.06.12.21258813; this version posted July 17, 2021. The copyright holder for this preprint (which was not certified by peer review) is the author/funder, who has granted medRxiv a license to display the preprint in perpetuity.

\section{Supplemental Table of Contents}

Table S1: Qualitative serological test results in the 3 study groups at different time points

Table S2: Quantitative serological test results in the 3 study groups at different time points

Figure S1: Timeline of COVID-19 infection and vaccination events split by study groups

Figure S2: $\quad$ Transplant group-specific associations with numerical results of anti S1/S2 SARS-

CoV 2 IgG serology testing

Figure S3: Dialysis group-specific associations with numerical results of anti S1/S2 SARS-CoV-

2 IgG serology testing

Figure S4: Further associations between vaccine inoculation, anti S1/S2 IgG test results and

COVID-19 infection

Suppl. Text: Mortality

Figure S5: Mortality in COVID-19 infection events among study participants 
medRxiv preprint doi: https://doi.org/10.1101/2021.06.12.21258813; this version posted July 17, 2021. The copyright holder for this preprint (which was not certified by peer review) is the author/funder, who has granted medRxiv a license to display the preprint in perpetuity. All rights reserved. No reuse allowed without permission.

Table 1: Demographic and clinical characteristics according to study group

\begin{tabular}{|c|c|c|c|c|c|}
\hline & & $\begin{array}{l}\text { Control } \\
\mathrm{N}=71\end{array}$ & $\begin{array}{l}\text { Dialysis } \\
\mathrm{N}=175\end{array}$ & $\begin{array}{c}\text { Transplant } \\
\mathrm{N}=252\end{array}$ & $\mathrm{p}$-value \\
\hline Age, years & mean (SD) & $43.6(14.3)$ & $65.1(15.0)$ & $53.5(14.4)$ & $<0.001$ \\
\hline \multirow[t]{2}{*}{ Sex } & female & $46(64.8)$ & $70(40.0)$ & $84(33.3)$ & $<0.001$ \\
\hline & male & $25(35.2)$ & $105(60.0)$ & $168(66.7)$ & \\
\hline \multirow[t]{2}{*}{ Hypertension } & no & $69(97.2)$ & $102(58.3)$ & $170(67.5)$ & $<0.001$ \\
\hline & yes & $2(2.8)$ & $73(41.7)$ & $82(32.5)$ & \\
\hline \multirow[t]{2}{*}{ Diabetes } & no & $70(98.6)$ & $118(67.4)$ & $203(80.6)$ & $<0.001$ \\
\hline & yes & $1(1.4)$ & $57(32.6)$ & $49(19.4)$ & \\
\hline \multirow[t]{2}{*}{ Prior COVID-19 } & no & $66(93.0)$ & $159(90.9)$ & 229 (90.9) & 0.848 \\
\hline & yes & $5(7.0)$ & $16(9.1)$ & $23(9.1)$ & \\
\hline \multirow[t]{3}{*}{ Vaccine inoculations } & 0 & 12 (16.9) & 31 (17.7) & $41(16.3)$ & 0.732 \\
\hline & 1 & $3(4.2)$ & $6(3.4)$ & $16(6.3)$ & \\
\hline & 2 & $56(78.9)$ & $138(78.9)$ & $195(77.4)$ & \\
\hline Time from Tx, years & median (range) & & & $4.0(0.25-49.0)$ & \\
\hline Dialysis vintage, years & median (range) & - & $2.8(0.47-18.6)$ & - & - \\
\hline Urea reduction rate, \% & mean (SD) & - & $72.1(8.2)$ & - & - \\
\hline Creatinine, $\mu \mathrm{mol} / \mathrm{I}$ & medan (IQR) & $67.5(16.5)$ & - & $123.3(73.4)$ & $<0.001$ \\
\hline eGFR, $\mathrm{ml} / \mathrm{min} / 1.73 \mathrm{~m}^{2}$ & mean (SD) & $92.4(17.5)$ & - & $52.8(21.8)$ & $<0.001$ \\
\hline Tacrolimus $^{1}, \mathrm{ng} / \mathrm{ml}$ & mean (SD) & - & - & $6.8(1.9)$ & - \\
\hline Hemoglobin, g/dl & mean (SD) & $13.6(1.6)$ & $10.5(1.1)$ & $12.8(1.8)$ & $<0.001$ \\
\hline WBC count per $\mu \mathrm{l}$ & mean (SD) & $7.6(1.9)$ & $7.6(2.7)$ & $8.4(2.4)$ & 0.004 \\
\hline Lymphocytes per $\mu \mathrm{l}$ & mean $(S D)$ & $2.2(0.7)$ & $1.2(0.6)$ & $1.7(0.9)$ & $<0.001$ \\
\hline
\end{tabular}

\footnotetext{
${ }^{1}$ Tacrolimus in $83 \%$, everolimus $9 \%$, cyclosporine (multiplied by 0.06 ) $7 \%$, sirolimus $1 \%$
} 
medRxiv preprint doi: https://doi.org/10.1101/2021.06.12.21258813; this version posted July 17, 2021. The copyright holder for this preprint (which was not certified by peer review) is the author/funder, who has granted medRxiv a license to display the preprint in perpetuity.

\section{Figure legends}

Figure 1. Qualitative results of anti S1/S2 SARS-CoV 2 IgG serology testing. (a) Distribution of categorical results among the study groups along the study time points. (b) Model prediction of IgG positivity rates in the 3 study groups according to the timing of testing in relation to the 1 st vaccination. (c) Model prediction of IgG positivity rates in the 3 study groups at different time points according to participant's age.

Definitions: "pre.v1", before vaccination; "post.v1", between vaccinations; "post.v2", up to 10 weeks after the 2 nd vaccine; "post.v2.3m", more than 10 weeks after the 2 nd vaccine ( 3 months post 1st vaccine); "post.COVID", after COVID-19 infection (regardless of vaccination status).

Figure 2: Numerical results of anti S1/S2 SARS-CoV 2 IgG serology testing. (a) Dot- and box-plots showing antibody titers (log scale) in the 3 study groups at 5 specified time points. (b) Scatter plot showing antibody titers (log scale) versus time after 1st vaccine in the 3 study groups. Repeat measurements from the same participant are connected with lines. (c) Model prediction of IgG titers versus age in the 3 study groups at different time points. (d) Model prediction of IgG titers versus time after 1st vaccination in the 3 study groups. See Figure 1 legend for time point definition. The dashed yellow lines represent the borderline titer range.

Figure 3: Associations between vaccine inoculation, anti S1/S2 IgG test results and COVID-19 infection. (a) Probability of COVID-19 infection from epidemic onset according to vaccination status as a time varying covariate (see Methods), split by study group. The inset shows the unspilt curves (all study groups). ${ }^{*}, \mathrm{p}<0.05$ for 2 vs. $0-1$ inoculations. (b) Risk of COVID-19 infection by inoculation status and age group. (c) COVID-19 events presented as Kaplan Meier curves according to IgG serology status. (d) Determinants of COVID-19 risk in a model including IgG titer as a time varying covariate. In (c) and (d) he green star marks the beginning of the vaccination period. 
medRxiv preprint doi: https://doi.org/10.1101/2021.06.12.21258813; this version posted July 17, 2021. The copyright holder for this preprint (which was not certified by peer review) is the author/funder, who has granted medRxiv a license to display the preprint in perpetuity. All rights reserved. No reuse allowed without permission.

Figure 4: Comparison of post-vaccination with post-COVID-19 infection anti S1/S2 SARS-CoV 2 IgG titers. (a) Dot- and violin plots showing IgG titers post COVID-19 vaccination ("post.v2") or infection ("post.COVID"). Also shown are the means and confidence limits (based on the tdistribution). (b) Model prediction of IgG titer versus age post-infection and post-vaccination in the 3 study groups, showing higher predicted titers post vaccine in controls but not in the ESRD groups. 
medRxiv preprint doi: https://doi.org/10.1101/2021.06.12.21258813; this version posted July 17, 2021. The copyright holder for this preprint (which was not certified by peer review) is the author/funder, who has granted medRxiv a license to display the preprint in perpetuity. All rights reserved. No reuse allowed without permission.

Figure 1

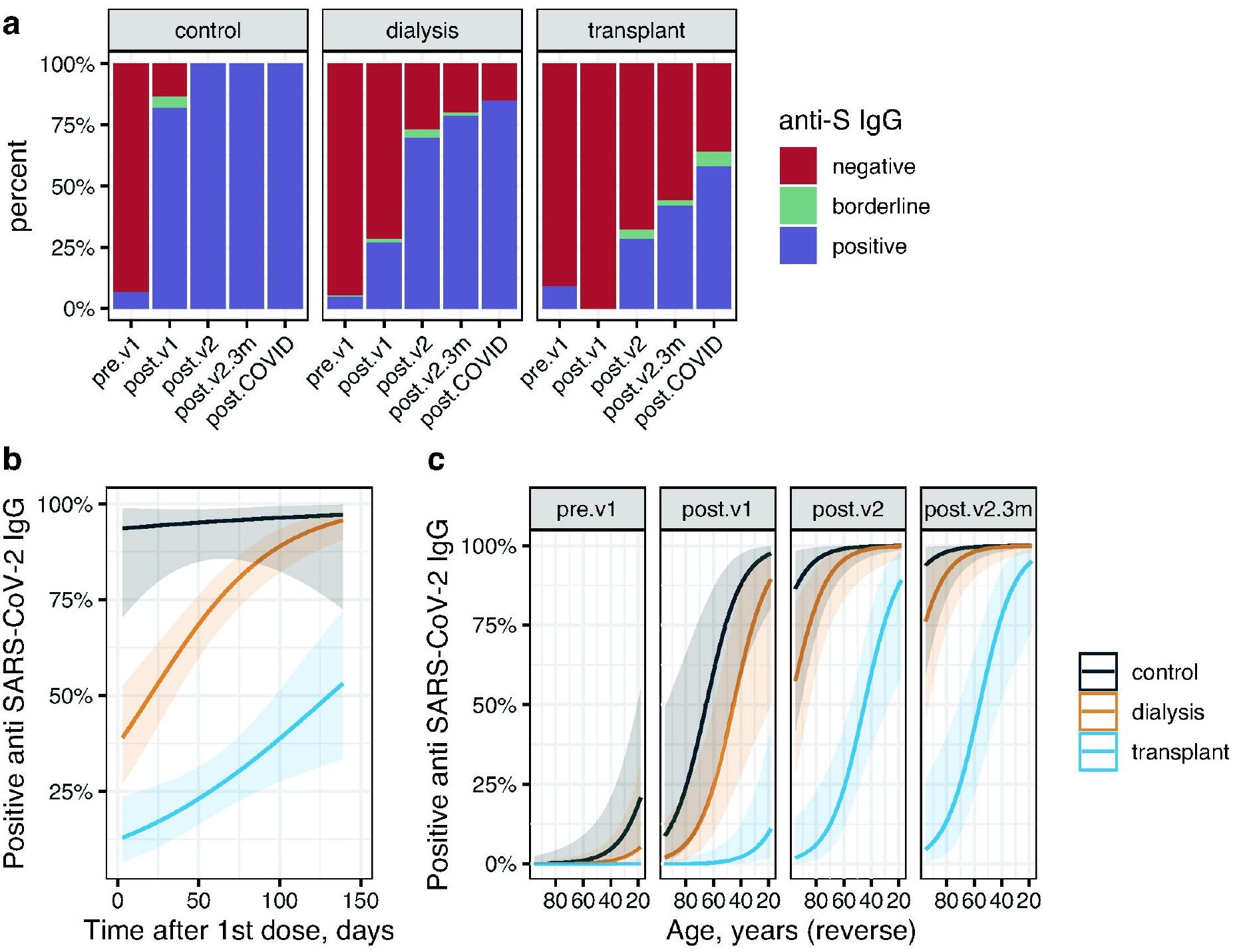


Figure 2

a

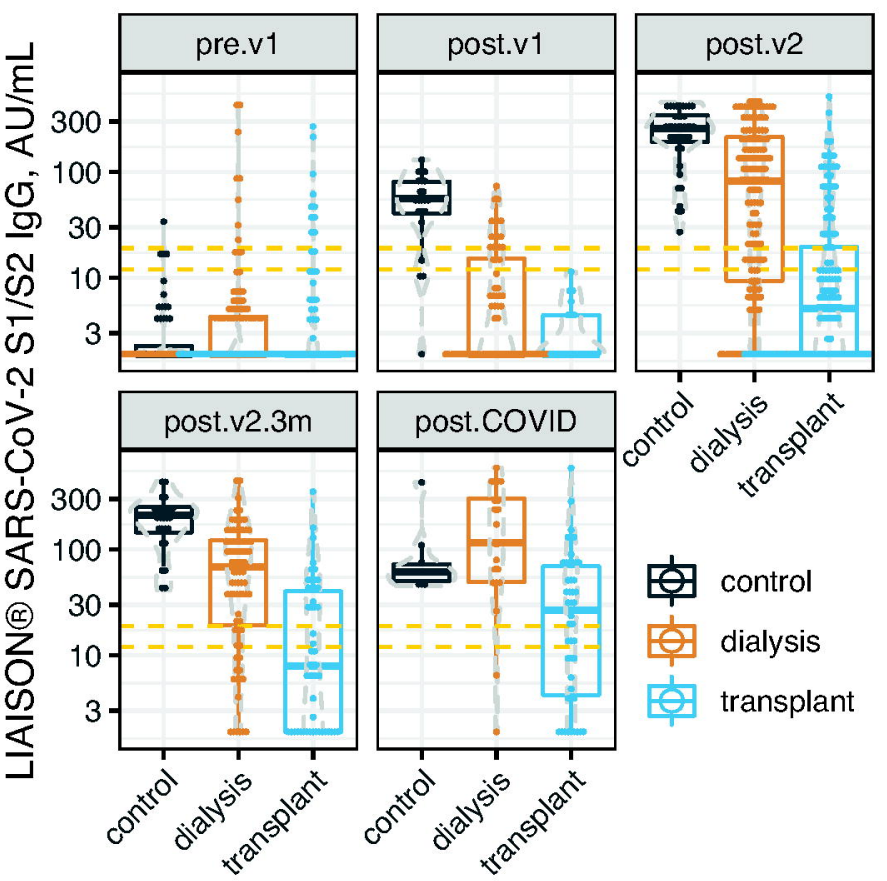

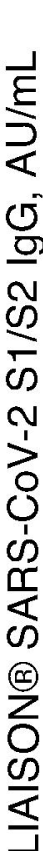

C

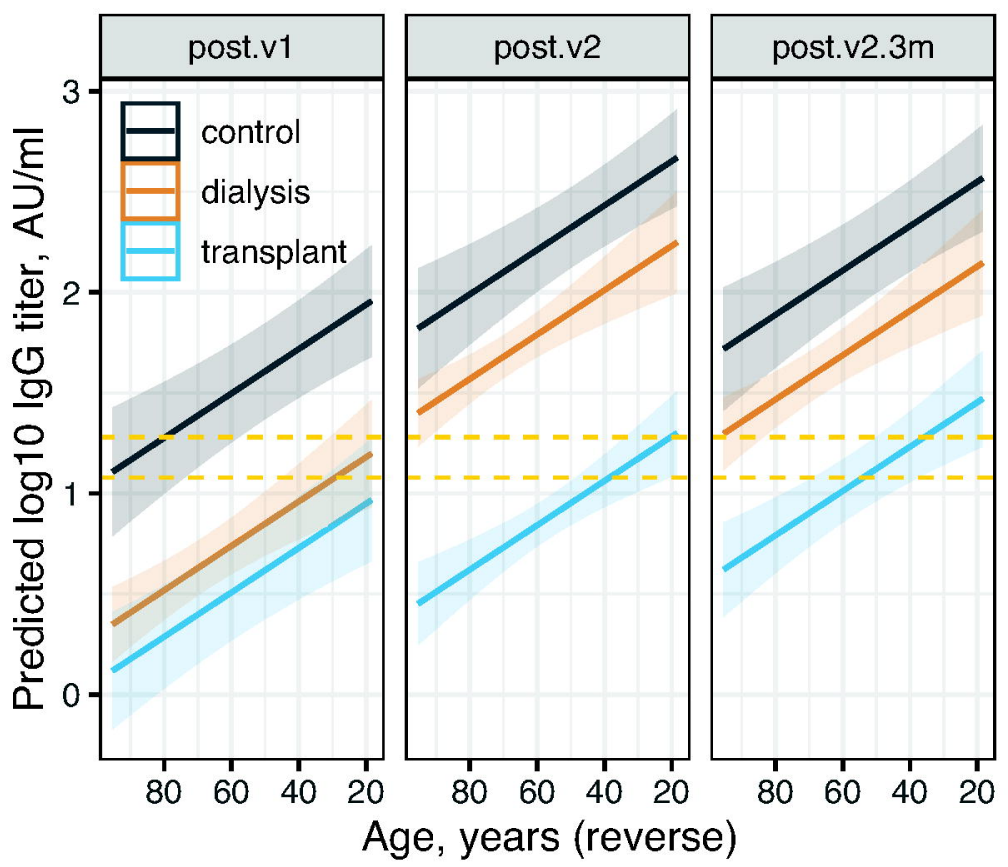

d
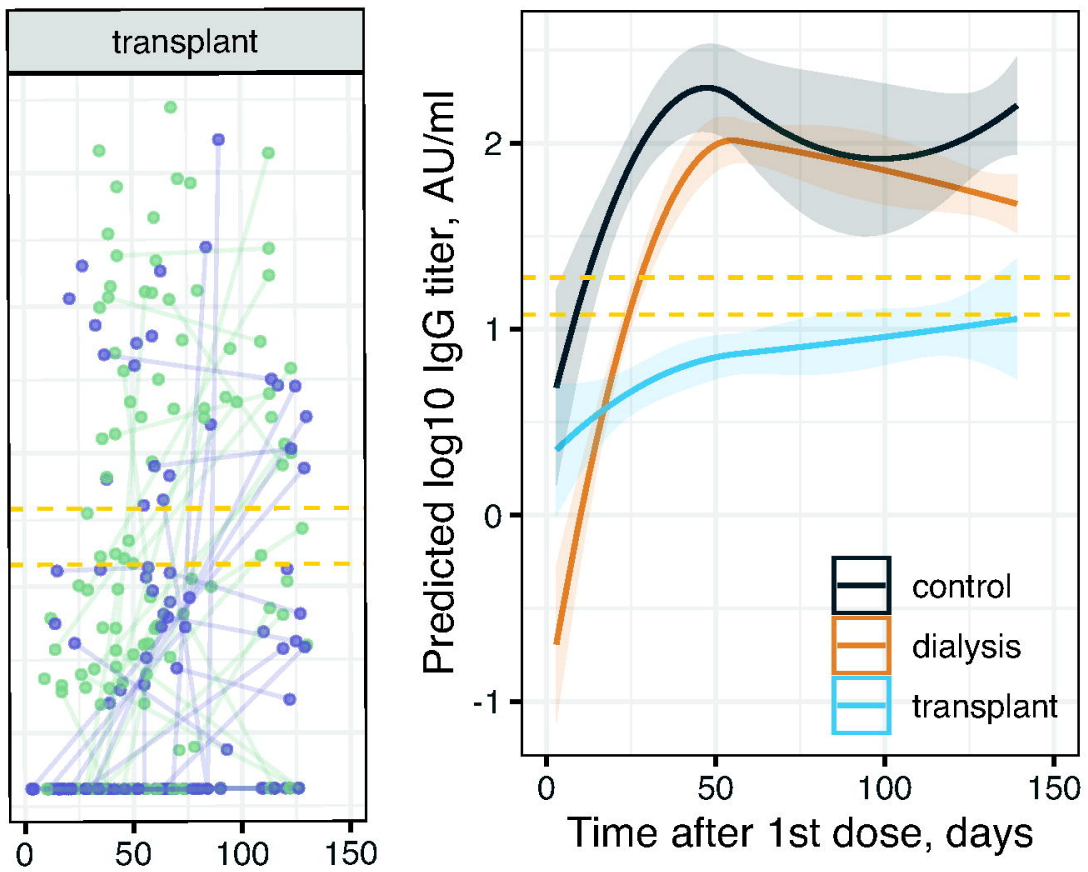
Figure 3

a

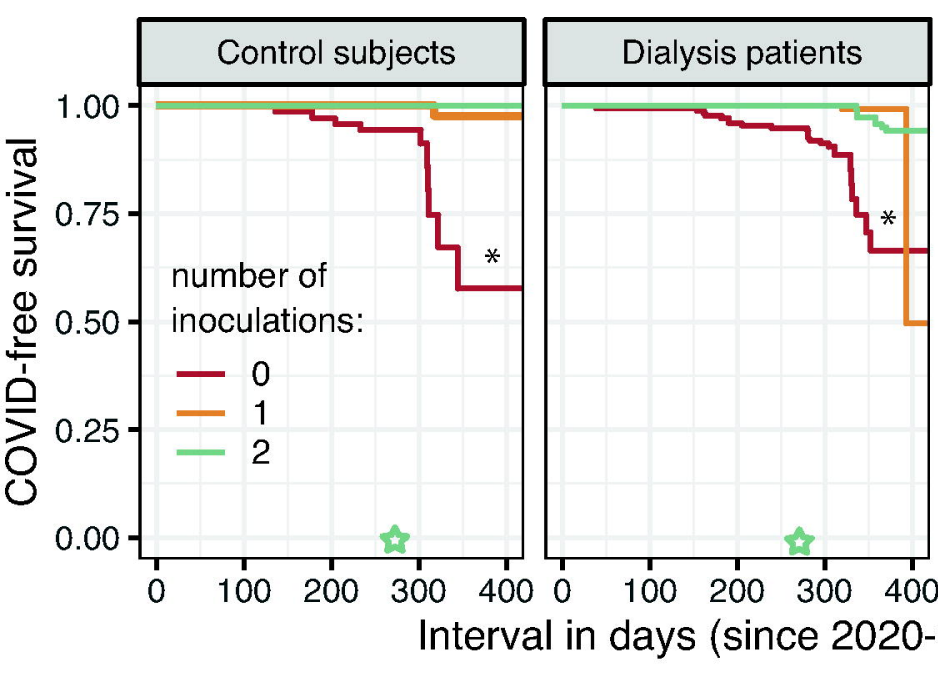

C

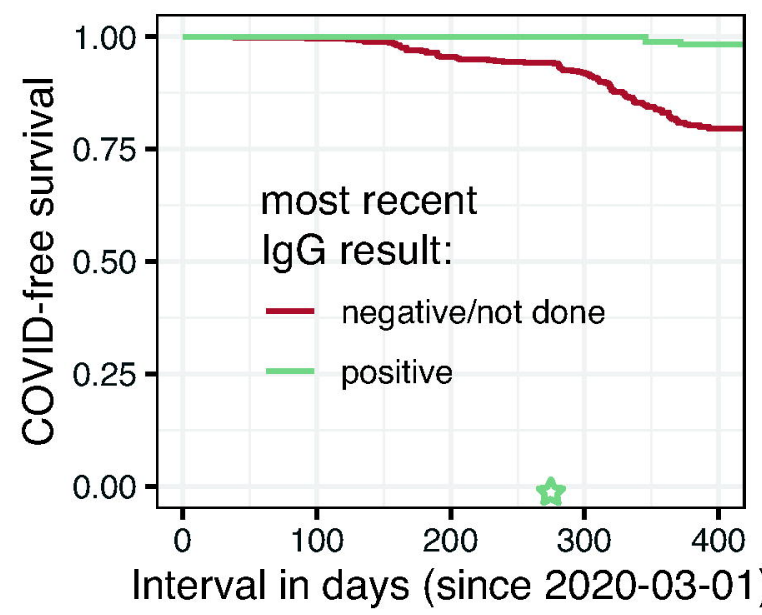

b

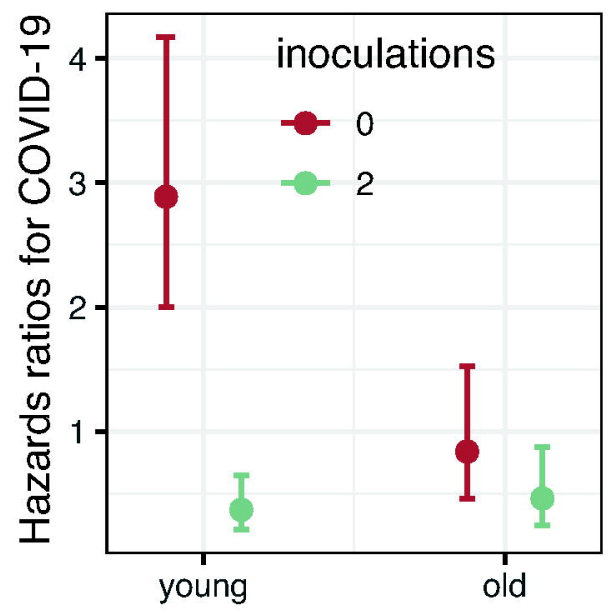


medRxiv preprint doi: https://doi.org/10.1101/2021.06.12.21258813; this version posted July 17, 2021. The copyright holder for this preprint (which was not certified by peer review) is the author/funder, who has granted medRxiv a license to display the preprint in perpetuity. All rights reserved. No reuse allowed without permission.

Figure 4

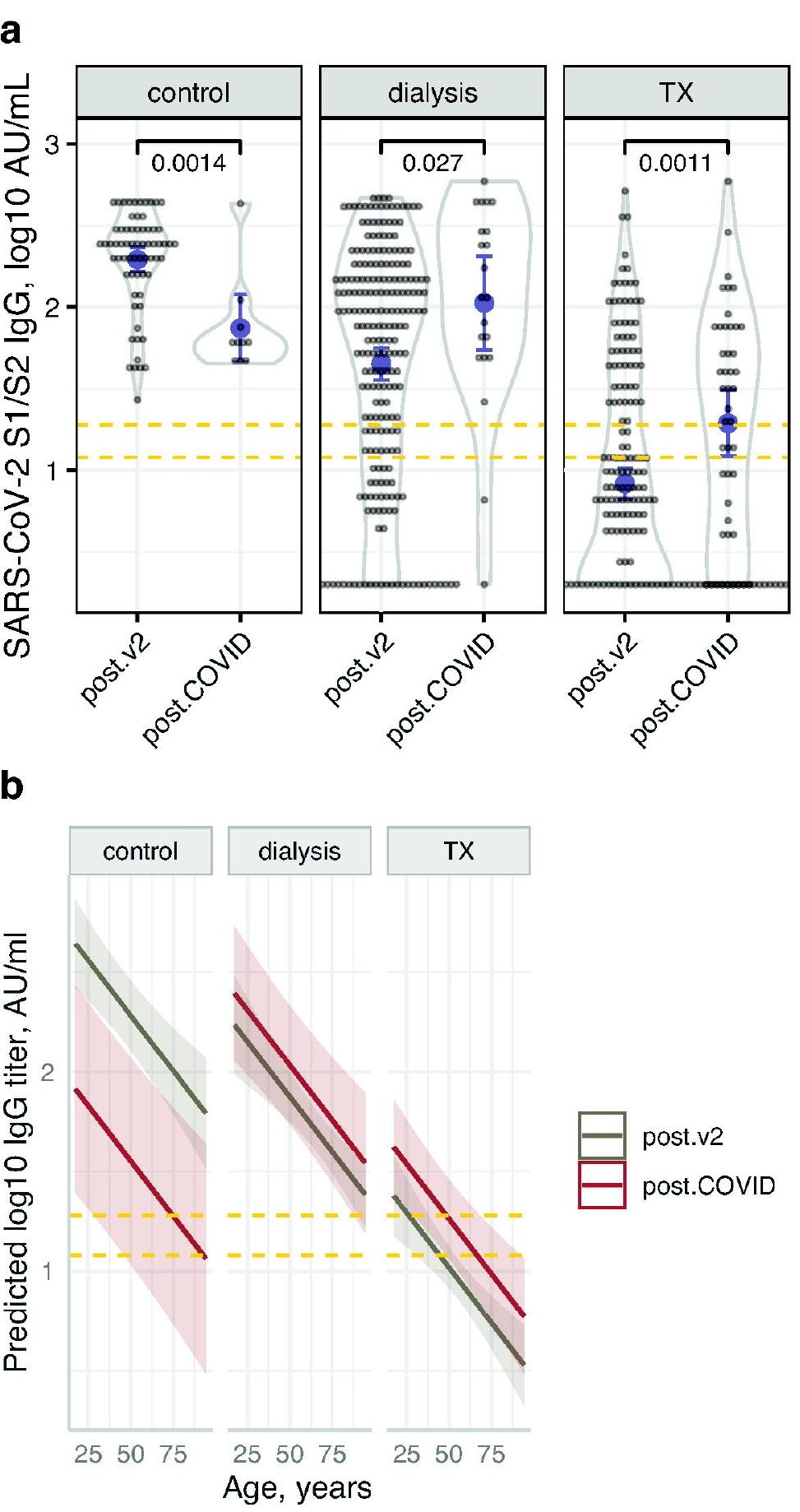

